\title{
Fall armyworm: Menace to Nepalese farming and the integrated management approaches
}

\author{
Srisha Bista ${ }^{1}$, Manisha Kumari Thapa ${ }^{2}$, and Saugat Khanal ${ }^{3 *}$
}

\author{
${ }^{1}$ College of Natural Resource Management, Agriculture and Forestry University, Puranchaur, Kaski, Nepal \\ ${ }^{2}$ College of Natural Resource Management, Agriculture and Forestry University, Pakhribas, Dhankuta, Nepal \\ ${ }^{3}$ Faculty of Agriculture, Agriculture and Forestry University, Rampur, Chitwan, Nepal \\ *Correspondence email id: ksaugat506@gmail.com
}

\begin{abstract}
Having worldwide spread from its native American distribution to Africa and Asia since 2016, the fall armyworm (Spodoptera frugiperda) is a crop pest species that has entered Nepal in May 2019 and distributed all over in a rapid way. Nepal is an agrarian nation and the majority of the farmers grow maize on a large scale. This pest has found to affect the maize substantially and damages all the crops entirely declining the yield heavily. This is a menace to maize farmers and poses a major threat to food security and agricultural trade. Thus this review focuses on the assessment of biology of the pest and the possible management approaches which the smallholder maize farmers could afford. Integrated pest management approaches, the integration of physical, chemical, and biological method, is adopted by the majority of the corn producers to reduce the impact of the pest on the crops. Different national and international organizations and institutions have been working to develop the strategies for effective control of such a harmful insect in Nepal.
\end{abstract}

Keywords - biology, control, fall armyworm, farmer's nightmare, maize, strategies.

\section{INTRODUCTION}

Fall Armyworm (FAW), Spodoptera frugiperda, an insect belonging to class-Insecta, order-Lepidoptera and familyNoctuidae, is native to tropical and subtropical regions of America (CABI, 2017; FAO, 2017) in the western hemisphere (Capinera, 2001). It is a polyphagous natured insect (Hoy, 2013) which feeds on 186 plant species from 42 families (Early et al., 2018). Even though it is ubiquitous in distribution (Dhungel et al, 2019), it is predominantly present in the zones which have a climate of very little frost cover, a minimum annual temperature of $18-26^{\circ} \mathrm{C}$ and $500-700 \mathrm{~mm}$ rainfall (Early et al., 2018). The record reported that it canfly $100 \mathrm{~km}$ per night (Capinera, 2001). Severe damage is seen on plants by FAW at its larval stage, especially on maize, rice, and sorghum (Dhungel et al., 2019). Nepal, being an agrarian nation, the majority of the people depends on farming for their livelihood. GDP from the agriculture sector contributes $27 \%$ (Khatiwada, 2019). The major cereal crops-Rice, maize, wheat, millet, etc. contribute majorly in the agriculture sector of Nepal. The temperature range is highly suitable for the establishment of this pest. In this degree, Nepal is considered as vulnerable to this pest. Maize strain and rice strain are the two common strains of FAW (Frerot et al., 2017).Maize is the third most important cereal crop next to wheat and rice globally, known as 'Queen of cereals (Jeyraman, 2017). Particularly, it is cultivated in hilly areas which are used in major food and feed industry. Loss of yield in maize results in higher demand for maize and dependency of it on other countries. Biodiversity is threatened by biotic pollution caused by fall armyworm (FAW).If FAW infestation spreads in this way, there will be major threats for the farmers of Nepal. In Argentina, food security was threatened by the highest yield loss (72\%) and $15-73 \%$ yield loss is shown by FAW's infestations in maize (Hruska and Gould, 1997). Farming in Nepal is based on subsistence type, the most cultivated product is consumed by a family member and only the rest of them are for selling. The farmers of Nepal would be impacted by damage of FAW if infestation and spreading of this pest increase to a greater extent. Farmers are confronting challenges on "how to control this pest?" In Nepal, there is aninadequate knowledge of pest and 
its management option. There is a lack of sound contingency and long term plans, coordinated researches, development, and intervention. There is a paucity of financial and material resources. So, it is time to think about pests that cause damage to the produced high-value crops. As fall armyworm cause major damage to this crop, the livelihood of a farmer is majorly affected. Sustainable crop management should be done to control this pest.

The effective control of fall armyworm is difficult but surely not impossible. Different related institutes like IRRI, CIMMYT, FAO,etc. are emphasizing on its control measure. Various insect resistant varieties have been developed to date. Also, different trainings, awareness programs, workshops, and conferenceshave been conducted to increase the general knowledge of pests for farmers by different organizations. Plant quarantine measures and legislation is made by government of Nepal in different quarantine centers of Nepal in the boarder of India-Nepal to prevent invasion of this detrimental pest. Several approaches by which integrated practices of economic control are done to suppress pest population, which is known as integrated pest management (IPM).However, government should put in 'place emergency plan'. These include monitoring with pheromone traps to determine the spread of FAW, roadside show to increase public awareness, a temporary ban on transportation of crop between two nations, restriction on transportation of plant material without checking properly. Economic and effective management of this pest should be done otherwise; it would ruin farmers' lifestyle.IPM is the integrated use of different techniques to suppress pest population which cause less harm to environment and people. Objectives of IPM are to prevent or avoid pest population, implement routine scouting to identify and respond to damaging pesticide and to suppress the pest using combination of biological, physical, cultural, and if necessary chemical approaches (Prasanna et al., 2018). Surveillance, scouting, and monitoring system should be promoted. Sustainable management option should be practiced on the basis of integrated pest management system. Government should empower and invest on research of this pest. Proper extension service should be provided to the farmers. Avoid of this pest is done by choosing quality seed in many cases. This paper aims to assess the threats of fall armyworm to maize production and the possible management approaches to reduce the attack of pests.

\section{RESEARCH METHODOLOGY}

This review completely uses secondary sources of information. Pieces of Literature were collected from different Journal articles, Agricultural institutes, other sources like FAO, CIMMYT, and relevant reports were studied and the major findings were summarized. Also, suggestions from related professors and officers were considered in the paper.

\section{DISCUSSION}

\section{Scenario analysis of maize productions in Nepal}

Maize cultivation is a way of life for most farmers of Nepal, especially in the hilly region. Maize is the most widely grown crop in Nepal after paddy in terms of acreage and productions and also a staple food for many people of the country. Although the report showed the slight increment in the yield of maize over the past decade, there has been very little improvement in yield when compared to average yield of the nation few years ago. The only plausible explanation behind the statement is probably the expansion of maize cultivation into less suitable terrain, degrading soil fertility status, sluggish adoption of advanced management approaches, and most importantly; the outbreak of severe pests and diseases such as fall armyworm. The 2020 maize crops, ready to be harvested from August onwards, are growing under appropriate weather conditions. The area cultivated is approximated at a high level, enduring the constant increase observed during the past eight consecutive years, signifying the strong demand by the feed industry (FAO, Global Information and Early Warning System, 2020). 


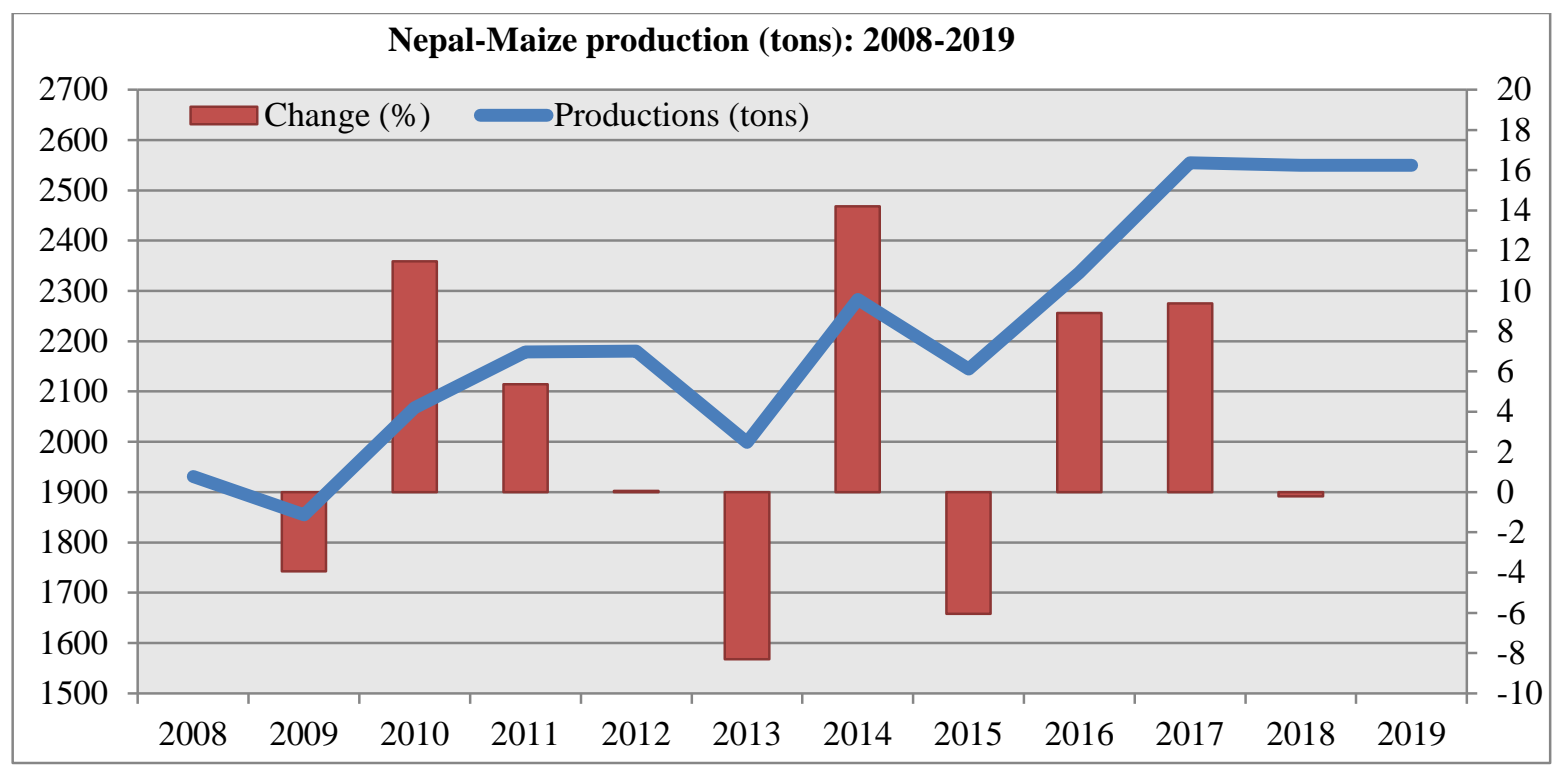

Fig.1 Scenario analysis of maize productions in Nepal: 2008-2019

Source: (Knoema, 2020)

In 2019, maize production for Nepal was 2,550 tons. Maize production of Nepal increased from 1931 tons in 2008 to 2,550 tons in 2019. Since a few years, the production has not increased as expected though there is advancement in agricultural technologies and the development of new innovations. The crop has been largely affected by the severe outbreak of dangerous insect-like fall armyworm. Maize cultivating areas are also increasing representing $25 \%$ of the total field area of cereal. $20 \%$ food and energy of people and $80 \%$ poultry and animal feed is supplied by maize. Maize productivity is declining year wise due to pest infestation among which FAW is a major pest. Young leaf whorls, ears, tassel and almost all parts are eaten by FAW, which is considered as a major feed for FAW, resulting in occasional total yield loss.

\section{Origin and distribution of Fall Armyworm}

This pest was limited to America until 2015 AD and recorded first time in Nigeria in 2016. According to Goergen et al. (2016), the FAW originated from the tropical regions of the Americas from the United States to Argentina and the Caribbean region. In 2018 AD FAW was recorded in Asia from Karnataka, India. In 9th August, 2019 FAW was first recorded in Nawalparasi, Nepal. Including Nepal, it has invaded 10 countries in the Asia (Poudel, 2020).It is a prime noctuid pest of maize and has remained confined there despite occasional interceptions by European quarantine services in recent years and has been recently introduced into the African continent and has already moved to at least 21 countries where the pest has been reported for the past 16 months (Abrahams et al., 2017). The genus Spodoptera comprises of 31 species with seven species previously recorded from the Afro-tropical region while six species are known to occur in West and Central Africa (Pogue, 2002). Sopodoptera exempta or African armyworm is the most common and well known amongst them in Africa.

Table 1 distribution of Fall Armyworm

\begin{tabular}{ll}
\hline Countries & First reported \\
\hline Nigeria & 2016 \\
Benin & 2016 \\
Angola & 2017 \\
India & 2018 \\
Nepal & 2019 (May) \\
Thailand & 2018 \\
Pakistan & 2019 \\
Srilanka & 2019 (January) \\
China & 2019 (January) \\
Australia & 2020 (February) \\
Papua New Guinea & 2020 (April) \\
\hline
\end{tabular}

Source: (FAO, 2020) 
In July 2018, it was observed in India and Yemen. By December 2018, FAW was recorded in Bangladesh, Sri Lanka and Thailand. As of June 2019, it was seen in Myanmar, China, Indonesia, Laos, Malaysia, Viet Nam, Egypt and the Republic of Korea. Japan recorded the outbreak of FAW in July 2019. FAW was officially reported in Australia and Mauritania in February 2020 and in TimorLeste in March 2020. The FAO map above shows the areas affected by Fall Armyworm.

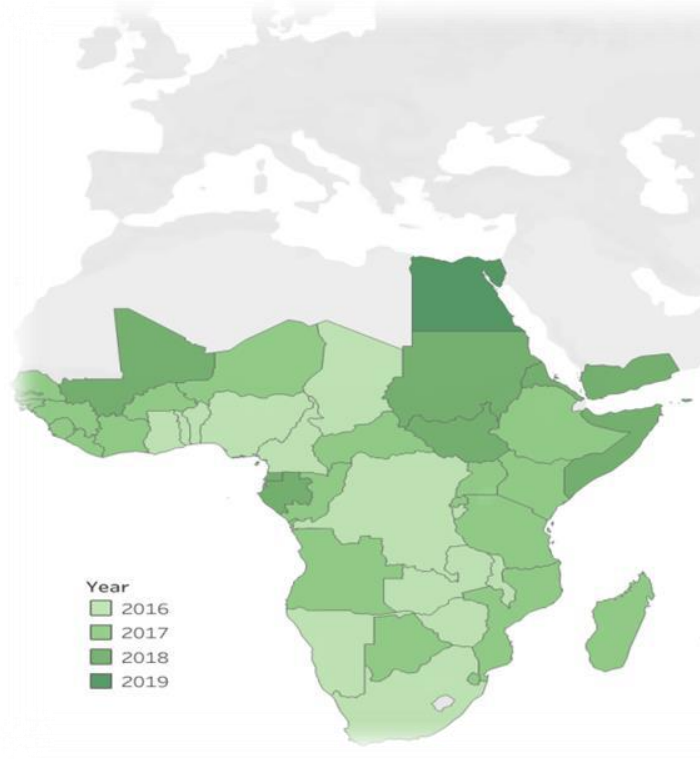

Fig2 Global status of FAW

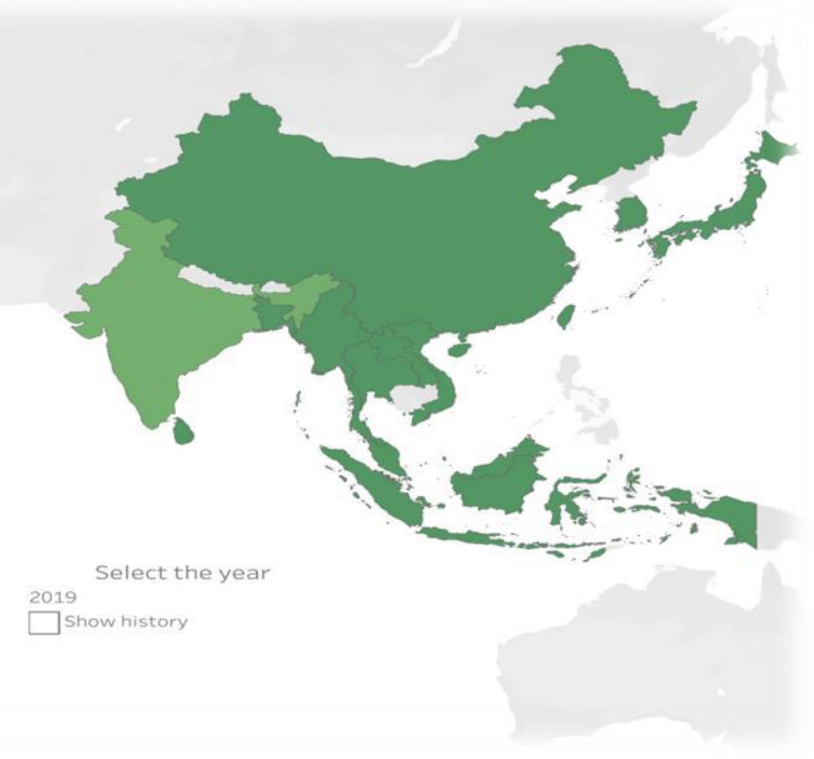

Source: FAO (2020)

\section{Classification of Fall Armyworm}

Kingdom: Animalia

Phylum: Arthropoda

Class: Insecta

Order: Lepidoptera

Family: Noctuidae

Genus: Spodoptera

Species: Frugiperda

\section{Identification of insect}

Eggs of FAW can be recognizedon the basis of the clustered laying nature of the eggs ranging from few to hundreds in numbers (Sparks 1979; Sharanabasappa et al., 2018). Eggs are laid on single or multiple layers creamy colored with anal tuft of hairs or sometimes without hair cover (Firake, 2019, p. 9). Eggs are usually spherical in shape and laybeneath the leaves, near the base of the plant, close to the junction of the leaf and the stem (CABI, 2019, p. 21). Identification of larvae in the field needs expertise and skills as FAW is easily confused with similar species such as the African armyworm

(Spodoptera exempta), and the cotton leaf worm (Spodoptera littoralis), as well as species of other noctuid genera. First instar larvae are greenish with a black head capsule, and later turned greenish-brown in the second instars. Larvae darken in color as they feed and appear greenish (Luginbill, 1969) .The third instars are brownish with three dorsal and lateral white lines. Fourth to the sixth instars are brownish black and had three white dorsal lines and alight lateral line (Sharanabasappa et al., 2018). The mature larva has a dark head with an upside down pale Y-shaped marking in head area and black four spots arranged in square in last abdominal segment (CABI, 2017). In male moth, the forewings generally shaded grey and brown, with the triangular white spot at the tip and near the center of the wing while the forewings of the females are less distinctly marked, ranging from the uniformly greyish brown to fine mottling of grey and brown (Prasanna.et.al., 2019).

\section{Biology of the pest}

The lepidopteron pest, fall armyworm has four stages in life cycle; viz: egg, larva, pupa, and adult. The fall armyworm feeds on leaves and stems of more than 80 plant species, causing significant damage to maize, rice, sorghum, 
sugarcane but also other vegetable crops and cotton (CABI,2020). Its life cycle is completed in about 30 days during the summer. However, it takes 60 days in the spring and autumn, and 80 to 90 days during the winter (Capinera, July 1999).

Egg:

Eggs are spherical in shape and the number of eggs per mass varies often between 100 and 200. Total egg production per female over her lifetime averages about 1500, with a maximum of over 2,000 (CABI, 2019, p. 21). Incubation period ranged from 2-3 days with a mean of 2.50 days with favorable temperature $20-30^{\circ} \mathrm{C}$ (Sharanabasappa et al., 2018).

Larva:

There are six larval instar of fall armyworm. The duration of the stage of larva tends to be almost 14 days during the summer and 30 days during cool weather. The mean development time was estimated to be $3.3,1.7,1.5,1.5,2.0$, and 3.7 days for instars 1 to 6 , respectively, when larvae were reared at $25^{\circ} \mathrm{C}$. The larvae in the back consists of 3 yellow stripes followed by a black and again yellow stripe on the side whereas on the second to last segment, four dark spots are seen that forms a square $(\mathrm{FAO}, 2018)$.

Pupa:

The larva binds the particles of soil together to form a loose, oval and 20-30 mm long cocoon inside which a reddishbrown pupa measuring 14 to $18 \mathrm{~mm}$ in length and $4.5 \mathrm{~mm}$ in width resides. The duration of the stage of pupa is nearly eight to nine days during the summer, but reaches 20 to 30 days during the winter (CABI, 2019).

Adult:

Adults are nocturnal, and are most active during warm, humid evenings. Females deposit most of their eggs during the first four to five days of life, but some eggs may be laid for up to three weeks. Females can mate multiple times during this period and lay multiple egg masses, with a potential fecundity of up to 1,000 eggs per female (Heinrichs.A.E, 2018, p. 12). The adult can liveupto an average 10 days, with a range of about 7-21 days (Prasanna et al., 2018).The favorable temperature for adult is less than $30^{\circ} \mathrm{C}(\mathrm{CABI}, 2017)$.

Table 2 Characteristics of different stages of Fall armyworm

\begin{tabular}{|c|c|c|c|c|c|}
\hline Stage & Shape & Color & $\begin{array}{l}\text { Duration } \\
\text { (days) }\end{array}$ & $\begin{array}{l}\text { Suitable } \\
\text { temp. }\left({ }^{0} \mathrm{C}\right)\end{array}$ & Special characteristics \\
\hline Egg & $\begin{array}{l}\text { Spherical } \\
\text { (diameter: } 0.75 \\
\mathrm{~mm} \text { ) }\end{array}$ & $\begin{array}{l}\text { Greenish gray in } \\
\text { early stage and later } \\
\text { turns into brownish } \\
\text { black }\end{array}$ & $2-3$ & $20-30$ & $\begin{array}{l}\text { Female covered a layer of scales } \\
\text { (downy materials on the egg mass and } \\
\text { give moldy appearance. }\end{array}$ \\
\hline Larvae & $3-4 \mathrm{~cm}$ long & $\begin{array}{l}\text { greenish to brownish } \\
\text { with longitudinal } \\
\text { stripes }\end{array}$ & $14-21$ & $26-28$ & $\begin{array}{l}\text { Yellow colored inverted Y-shape } \\
\text { structure on the head, black dorsal } \\
\text { pinaculate with long primary and four } \\
\text { black spots arranged in a square on the } \\
\text { last abdominal segment. }\end{array}$ \\
\hline Pupa & $1.3-1.7 \mathrm{~cm}$ long & $\begin{array}{l}\text { Brownish in the } \\
\text { early stage and later } \\
\text { turned into back }\end{array}$ & $9-13$ & $13-16$ & A loose cocoon in an earthen cell \\
\hline Adult & $1.5-1.7 \mathrm{~cm}$ long & $\begin{array}{l}\text { Dark grey to brown, } \\
\text { straw }\end{array}$ & $12-14$ & below 30 & $\begin{array}{l}\text { Distinctive white spot near the dorsal } \\
\text { tip, or apex, of the wing, Forewing is } \\
\text { mottled. Hindwings are straw colored } \\
\text { with a dark brown margin }\end{array}$ \\
\hline
\end{tabular}

Source: (CABI, 2017) 


\section{Threats of fall armyworm: Farmer's nightmare}

An intrusive pest, fall armyworm (Spodoptera frugiperda) was first recorded in Nepal from Nawalpur district which are presumed to have entered from India (Poudel, 2020). As the world is confronting the perils of climate changes in agricultural productions, the outbreak of detrimental insect, fall armyworm, has added the challenges in farming sector. Fall armyworm is a hazardous trans boundary insect with a high likelihood to spread expeditiously due to its natural distribution capacity. (FAO, 2019) portrays a real menace to food security and livelihoods of millions of smallholder rural peasants. Several researchers have performed a research on destruction level of fall armyworm on various crops in Indonesia ( Maharani et al., 2019), Nepal (Bhusal and Bhattarai , 2019), Kenya (Groote et al., 2020), and many other countries.High fecundity of the insect at favorable environment condition is foreseen to result a severe damage to crops (Goergen et al., 2016). The larvae consumed both vegetative and reproductive structures of the crops. The young larvae mostly preferred the epidermal leaf tissues and make holes in the leaves; peculiar damage symptom of fall armyworm (Bhusal and Bhattarai , 2019). Loss of photosynthetic area, diminished reproduction, crop damage, lodging and structural damage in the whorl are shown on different researches by different researcher (Chimweta et al., 2019).

The fall armyworm (FAW) has harshly affected maize production across the country this year, 2020, as compared to previous year, 2019, hitting farmers who have already had to confront the burden of the coronavirus pandemic (The Himalayan Times, 2020). The catastrophic outbreak of the pest has threatened many small to large maize producers of the country. It has destroyed over thousands of hectares of maize fields from different districts across the country. In 2018, the Democratic republic of Congo reported that $45 \%$ of maize harvest losses occurred due to FAW attacks that resulted in a loss of 0.89 million tons of maize during harvest season (FAO, 2018).Similar cases were recorded in
Nicaragua; yield loss of over 70\% (Hruska and Gould , 1997), America; yield loss of 39\% ( Ivan et al., 2012), and Argentina; yield loss of $72 \%$ (Chamberlain et al., 2006). It causes substantial damage to maize by feeding on leaf whorls, ears and tassel which sometimes results in total yield loss (Sarmento et al., 2002). Although the direct foliar damage in maize from the attacks of fall armyworm is menacing too many farmers, the damage in many cases doesn't result in dramatic yield reduction (Hruska , 2019).The larvae, being voracious in nature, consume almost all the vegetation in their path. The consumption rate is high and the major damage is due to the feeding on the foliage. At the beginning, young larvae feeds on leaf tissue from one side and second or third instar larva make series of holes in the leaves and feeds on the edge of the leaves inwards. The older larva makes a huge damage leaving only ribs and stalk of corn. Because of its cannibalism nature, one or two larva is found per plant. Larvae also burrow the growing parts such as buds, whorl, etc. and hindered the growth of corn. It often infests ears as well. Such ears aren't consumed by humans. That's why the fall armyworm doesn't directly affect the food safety of maize; rather it can make the maize more susceptible to aflatoxin presence (Zanolli, 2018). The pest will consequently affect natural capital through economic yield losses and the capacity of farm lands to respond to shocks, and through increasing the cost of production which will ultimately affect household's social and physical capital (the household's assets). The pest also impact the import and export of the maize within or outside the country as it carries the risk of introducing pests to areas where the pests are not yet present. For the reasons, it has become a great nightmare particularly to maize crop farmers. The alarming pest has a voracious appetite for corn and other cereal crops and its impact would be noteworthy for the Nepalese farmers and country's economy ( Beshir et al., 2019). The insects prefer maize - a key food crop in Nepal - as well as rice, sorghum, millet, potato, sugarcane, vegetable crops and cotton. 


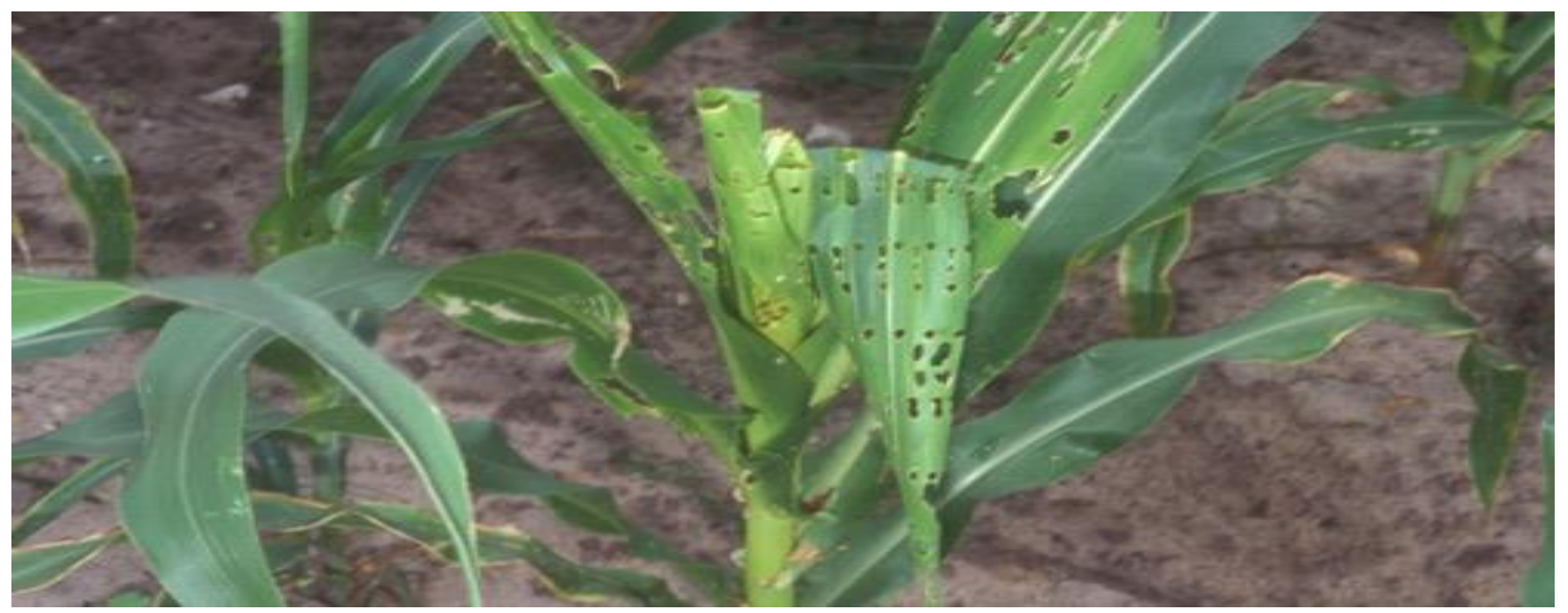

Fig 3: Corn leaf damage caused by the fall armyworm, Spodoptera frugiperda

\section{Control/management}

Sensing Fall Armyworm infestation before it causes heavy damage is the key to their management and control. Its management should be done cautiously as it is a dangerous pest. Only one method is not sufficient for the control of this pest. Different system should be integrated to control effectively.

\section{Integrated management of fall armyworm}

The best and most effective strategy to control FAW is taking preventive measures and immediate actions when the fall armyworm is detected. IPM focuses on the growth of a healthy crop with the least possible disruption to agroecosystems and encourages natural pest control mechanisms. Management of this pest should be done in such a way that sustain for eco-friendly environment, causes low risk to human environment, and also should be cost effective. Control of this pest is possible through many physical, biological, chemical, cultural means. Proper timing, selection of crop variety, crop management and proper use of bio-pesticides, and synthetic pesticides are important parameter of IPM. Right planting date is also important for its control. Late planted and late maturing varieties are susceptible to FAW infestation. Therefore, cultivation of maize variety which is genetically modified or early maturing type would be effective to control this pest. Btmaize has been found resistant to FAW (FAO, 2018). Good soil condition is another important aspect. Crop variety which completely covers maize cob should be selected. Unbalance use of fertilizer especially Nitrogen can lead to oviposition by female fall armyworm. Thus, it is recommended to use balance fertilizer which is organic. Proper knowledge of larval cycle of FAW and time of day for application of pesticide is also important parameter. If $5 \%$ seedlings are cut or $20 \%$ whorls of small plant are infested, it is recommended to apply an effective management practice to prevent further damage (FAO, 2018).

\subsection{Monitoring and scouting:}

Frequent observation and estimation of pest population and losses should be done in the maize field. FAW field monitoring is one of the key components of IPM. Three methods; Scouting, Pheromone trap and Light trap are used for the monitoring of the pest (Abrahams, 2017). The efficient method of monitoring this pest in the field is by using black light trap and Pheromone trap. Upto four pheromone traps per acre should be suspended at canopy height during the whorl stage of maize (Mwangi, 2019, May, p. 9). Mating interruption is possible through pheromone trap in which chemicals or sex pheromones are produced by female to attract males are placed which can move long distance through air and makes monitoring easy (Shorey, 1994). Insect catches indicate the presence of moths in the area but may not be accurate indicators of density (Global Fall Armyworm Management , 2019, p. 11). Light traps can be used to control the adult fall armyworm which helps to trap both male and female insects. Nocturnal behavior of FAW moth makes it possible to monitor easily through Black light trap (Hunt et al. 2001; Qureshi et al. 2006).

Scouting is the use of science based protocols by trained individual which is the process of precisely assessing pest 
pressure and crop performance for the effective solution of pest and disease control. Scouting promote farmers knowledge on biology of pest in the field and their ecology, which makes easier for farmer in decision making process for high yield, lower wasted resources and sustainability (FAO, 2018a). It is typically performed in order to evaluate both the economic risk of pest infestation and the potential efficiency of pest control interventions, with the goal of informing practical crop management decisions at the individual field and farm level (Prasanna et.al., 2019, p. 12). Usually, it can be done by walking in "W" pattern in the field after leaving 4-5 outer rows. . Action is taken if 5\% plant are damaged at seedling to early whorl stage, $10 \%$ whorl are damaged in mid whorl stage, $20 \%$ are damaged at late whorl stage (Kumbhar, 2019).

\subsection{Early warning system}

By warning farmers earlier on the futurerisk of FAW outbreaks, they have the likelihood to prevent crop damage.
On the basis ofrisk level, farmers are encouraged to scout their fields routinely for eggs and larvae and take precautionary measures where possible. Food security and food safety are very important for day-to-day life but outbreaks of harmful diseases and pest has imperiled farmer's life. Along with diagnosis-controlling, early forecasting is crucial which is known as Early Warning System (Li et al., 2007). Consolidating the principles of biology, ecology and mathematics is the basis of early warning system (Wang et al., 2013). It is a process in which collection and sorting of data, and generation of early warning information is done (Wang et al., 2013). Android application -"Fall Armyworm Monitoring and Early Warning System(FAMEWS)" was used in Madagascar and Zambia and successfully applied by African country which was developed by FAO (FAO, 2018c). Similar application can be developed in Nepal to monitor FAW effectively.

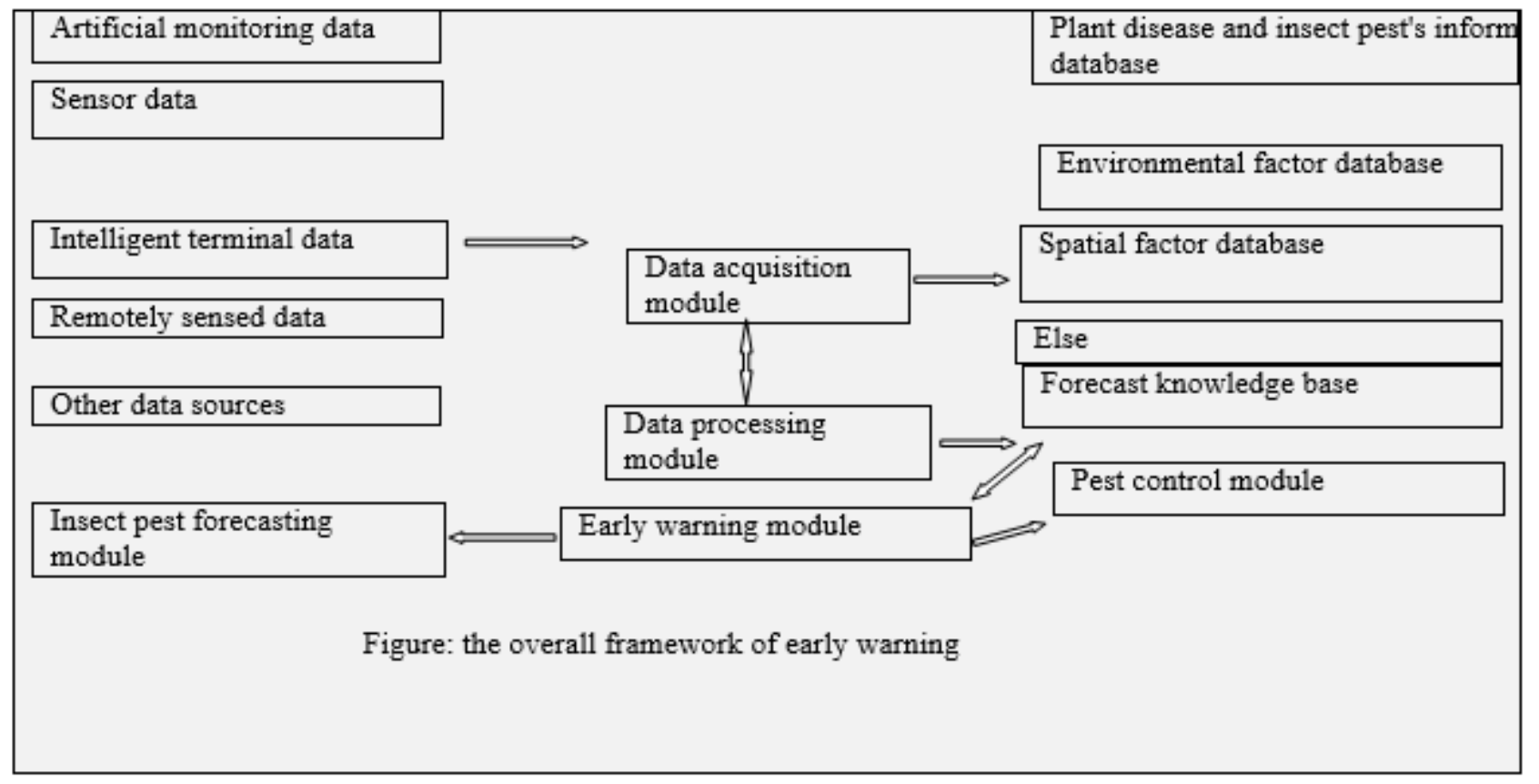

Fig 4 Framework of Early Warning System

Source: (Wang, 2013)

\subsection{Physical method of control}

It is the simplest method of pest control where FAW eggs and larvae are killed mechanically. During first week after planting, eggs which are laid on mass on maize leaves are immediately crushed. Young larvae are picked off the leaves, before invades inside whorl. Hand picking and destruction of egg masses during monitoring is done which helps to control the pest. In Ethiopia, $15 \%$ of the farmers practiced only handpicking for FAW management (Rwomushana, 2018) 
and crushing or immersing of larvae in masses. Application of dry sand in whorl is another method of controlling FAW by disturbing them. Soil application inside the whorl is done to control somehow.

\subsection{Cultural method}

Cultural control is an effective component of a pest control strategy for FAW. Deep ploughing has shown effective for controlling eggs and pupal stages of FAW. Planting of legumes as a trap crop and ploughing field rightly before planting the field can be an effective possible cultural method for managing the pest. Cultural practices like clean cultivation and proper use of fertilizers, grown of maize hybrids with tight husk cover will reduce ear damage by FAW (Firake, 2019). Timely sowing of seed could help to reduce pests. In whole one region planting date should be same which help Maize should be planted early. Balanced fertilizer should be applied. Neem based pesticide (Azadirachtin $1500 \mathrm{ppm}$ ) should be applied if there seems papery window on leave. Most farmers lack access to market and chemical pesticides. Use of Intercropping with leguminous crop i.e. French bean, soyabean, groundnut and other beans provide better protection to the crop compared to mono-cropping (Hailu et al., 2018). Erection of bird perches, sowing of trap crops, clean cultivation and balanced use of fertilizers, cultivation of maize hybrid with tight husk cover will reduce ear damage by FAW. Another important aspect is selection of crop variety. In case of Nepal, proper evaluation hasn't been done yet. Some GMO's including Bt-maize reported resistant in Africa, however FAW has overcome Btmaize in case of America (FAO, 2018).

Push-Pull Strategy: It is one of the important strategies for controlling the infestations of FAW. In this method, maize is intercropped with pest-repellent Desmodium spp. (Pushcrop), surrounded by pest-attractive Napier Grass, Pennisetum purpureum or Bracharia spp. as pull-crop (Dively, 2018). Napier grass attracts stem borers and FAW to lay egg on it but doesn't permit larval growth due to poor nutrition, so very few larvae remain alive. Desmodium emits volatile compound which is disliked by stem borer or FAW and repelling action happens thereafter. Combination of Desmodium green leaf and Bracharia cv. Mulato II known as 'Push-pull climate smart' was proved to be effective from different researches. Reduction of $82.7 \%$ in average number of larvae per plant and $86.7 \%$ in plant damage per plot have been observed in push-pull plot, compared to maize monocrop plots. Likewise, maize grain yields are recorded to be significantly higher, 2.7 times, in push-pull plots (Midega et al., 2018). Some of the promising practices identified are given in Table1 below:

Table 3 Cultural method of FAW management

\begin{tabular}{llll}
\hline S.N. & \multicolumn{1}{c}{ Method } & \multicolumn{1}{c}{ Description } & \multicolumn{1}{c}{ Reference } \\
\hline 1. & $\begin{array}{l}\text { Intercropping with } \\
\text { compatible companion } \\
\text { crops and fertilizer } \\
\text { trees. }\end{array}$ & $\begin{array}{l}\text { Planting additional crops in strips, rows, or stations between } \\
\text { the main crop (e.g., pigeon pea, cassava, sweet potatoes, } \\
\text { cowpea etc.) helps to reduce the infestation of FAW. }\end{array}$ & $\begin{array}{l}\text { Landis et al. (2000); } \\
\text { Intercropping with repellent plants such as Tephrosia and } \\
\text { Desmodium repel the adult female FAW moths and reduce } \\
\text { the number of eggs lay on host plants. }\end{array}$ \\
& Deep ploughing & $\begin{array}{l}\text { Deep ploughing before sowing helps to expose the pupae to } \\
\text { birds or predators. }\end{array}$ & (Mooventhan.P, 2019, p. \\
& & $\begin{array}{l}\text { Do not delay planting: take advantage of planting with the } \\
\text { first effective rains, as FAW populations build up later in the } \\
\text { crop season. }\end{array}$ & $\begin{array}{l}\text { Verg and Van Rensburg } \\
\text { (1991) }\end{array}$ \\
\hline 3. & Planting at the & & \\
recommended/ & optimal time & &
\end{tabular}




\begin{tabular}{|c|c|c|c|}
\hline 4. & $\begin{array}{l}\text { Conservation } \\
\text { agriculture }\end{array}$ & $\begin{array}{l}\text { Combined use of no tillage, residue retention, and rotation } \\
\text { increases and diversifies biological activity of macro-(spider, } \\
\text { beetles, and ants), meso-(fungi), and micro fauna (bacteria). } \\
\text { These practices also lead to improvement of soil health, } \\
\text { which contributes to more vigorous growth of the crop. }\end{array}$ & $\begin{array}{l}\text { All (1988); } \\
\text { Rivers } \\
\text { et al. (2016) }\end{array}$ \\
\hline 5. & $\begin{array}{l}\text { Increased ground } \\
\text { cover }\end{array}$ & $\begin{array}{l}\text { Cover crops like mucuna, lablab beans, jack bean, sun hemp, } \\
\text { etc., contribute to plant species diversity that enhances } \\
\text { biological activities and provides shelter for natural } \\
\text { Enemies (spiders, beetles, ants). }\end{array}$ & $\begin{array}{l}\text { Altieri } \\
\text { et al. (2012) }\end{array}$ \\
\hline 6. & Push and pull strategy & $\begin{array}{l}\text { In this strategy maize crop is intercropped with pest-repellent } \\
\text { "Push crop" i.e. Desmodium spp and "Pull crop" i.e. Napier } \\
\text { grass (Pennisetum purpureum) is panted in the border which } \\
\text { attracts the pest thus, FAW can be killed by spraying } \\
\text { insecticides in Napier grass only.Reductions in FAW } \\
\text { infestation are reported to be } 82.7 \% \text { in the average number of } \\
\text { larvae per plant and } 86.7 \% \text { in plant damage per plot in } \\
\text { climate-adapted push-pull compared to maize monocrop } \\
\text { plots. }\end{array}$ & (Dively, 2018) \\
\hline
\end{tabular}

\subsection{Biological control}

Biological control can be considered as a powerful tool and one of the most important alternative control measures providing environmentally safe and sustainable plant protection (Assefa.F .et .al, 2019). In situ protection of natural enemies by habitat management support to increase the plant diversity by intercropping with pulses and ornamental flowering plants which help in buildup of natural enemies (G. Ravi, 2019).Among several groups Telenomus remus and Trichogramma spp are effective to control pest in field. Biological control agents (BCAs) include the following:

a) predatory insects and mites, which eat their prey;

b) Parasitoids, which are insects with a free living adult stage and a larval stage that is parasitic on other insects.

c) Parasites and microbial pathogens, such as nematodes, fungi, bacteria, viruses and protozoa, which cause lethal infections. (FAO, 2018).

\section{Predator:}

Predators of the Fall Armyworm kill several individuals either as eggs, larvae, pupae or adults. The predators include earwigs, ladybird beetles, ground beetles, assassin, flower bugs, and predatory wasps. Birds, skunks, and rodents also feed on larvae and pupae of FAW among the vertebrate predators. Pair and Gross found 73\% FAW pupal mortality mainly due to predators. Generally,they are non-selective or generalists, so they feed opportunistically on more than one host species, often even on their own kind. The most preferred site of FAW in maize is the whorl inside which a predatory earwig, Doru luteipes (Scudder) lays its eggs (Reis et al., 1988) and occurs throughout the maize crop cycle. Nymphs of D. luteipes consume 8-12 larvae daily, while in the adult stage they consume 10-21 larvae of $S$. frugiperda daily (Reis et al., 1988). 
Table 4 Predators controlling FAW

\begin{tabular}{rll}
\hline S.N & Natural Enemy & Life Stage \\
\hline 1 & Calleida decora & Larva \\
2 & Calosoma alternans & Larva \\
3 & Calosoma sayi & Larva \\
4 & Carabidae & Larva/Pupa \\
5 & Doru luteipes & \\
6 & Doru taeniatum & \\
7 & Ectatomma ruidum & \\
8 & Geocoris punctipes & \\
9 & Steopolybia pallipes & \\
10 & Podisus maculiventris &
\end{tabular}

Source: (CABI, 2019)

\section{Parasitoid:}

Parasitoids are organisms whose adults lay eggs either inside or attached to a single host organism. To enable development, the resultant larvae feed on the tissues of the host until they are fully grown and pupate. Parasitoid larvae always kill their host as the outcome of their development.
The majority of parasitoids known to be associated with the FAW are wasps, and less frequently flies (FAO, 2018). The parasitoid Cotesia icipe (Hymenoptera: Braconidae) found to parasitize 33-45\% of FAW larvae (Global Fall Armyworm Management , 2019). Use of Parasitoids for the control of pest is effective for the environment and human health.

Table 5 Parasitoids controlling FAW

\begin{tabular}{llll}
\hline S.N. & Natural Enemy & Life stage & Host \\
\hline 1 & Archytus incertus & larva & maize \\
2 & Archytus marmoratus & larva/pupae & maize/sorghum \\
3 & Campoletis flavicincta & larva & maize \\
4 & Chelonus curvimaculatus & eggs/larva & maize \\
5 & Chelonus insularis & eggs/larva & maize/sorghum \\
6 & Cotesia marginiventris & larva & maize \\
7 & Cotesia ruficrus & larva & maize \\
8 & Euplectrus platypenae & larva & maize \\
9 & Glyptapanteles creatonoti & larva & maize \\
10 & Lespesia archippivora & larva & maize \\
11 & Microchelonus heliopae & eggs/larva & maize \\
12 & Brachymeria ovata & pupa & \\
13 & Telonomus remus & eggs & maize/vegetable \\
14 & Trichogramma achaeae & eggs & maize \\
\hline
\end{tabular}


International Journal of Environment, Agriculture and Biotechnology, 5(4)

Jul-Aug, 2020 / Available: https://ijeab.com/

\begin{tabular}{llll}
\hline 15 & Trichogramma chilotraeae & eggs & maize \\
16 & Trichogramma pretiosum & eggs & maize \\
17 & Trichogramma rojasi & eggs & maize \\
\hline
\end{tabular}

Source: (CABI, 2019)

\section{Pathogen:}

Pathogens are everywhere. Entomopathogens are those which affect insect. Pathogens are viruses, fungi, bacteria, nematode and protozoans. Mostly, virus, fungus, and bacteria play important role in controlling FAW. They are farmerfriendly pathogen which can be recycled by farmers easily in this process, dead-decayed larva which are found in field and contain full of viroid particle of fungal spore are taken from field and then they are grinded by kitchen blender. The liquid strain from these are taken and mixed with water. Then they are sprayed in infected plants. Nuclear polyhedrosis virus (NPVs) and Spodoptera frugiperda multi capsid nucleo polyhedrosis virus (Sf MNPV) are reported lethal to the
FAW. The host-specificity of pathogens is quite high, usually restricted to a few closely-related insect species (FAO, 2018). The larvae of the Fall Armyworm infected by a pathogen change the color with increasing paleness and decreasing movement, especially, when touched. However, the best way to identify a diseased larva is when it is already dead. Particularly for FAW larvae infected with Baculovirus the dead larvae will generally be observed in the upper parts of the maize plant and will hang upside down. Dead larvae covered with a powdery white or greenish mass suggest fungal infection (Prasanna et.al., 2019, p. 78). The major entomopathogens helpful for management of FAW are listed below in table.

Table 6 Pathogens controlling FAW

\begin{tabular}{cll}
\hline S.N. & Natural Enemy & Life Stage \\
\hline 1 & Bacillus cereus & Larvae \\
2 & Bacillus thuringiensis & Larvae \\
3 & Bacillus thuringiensis alesti & Larvae \\
4 & Bacillus thuringiensis darmstadiensis & Larvae \\
5 & Bacillus thuringiensis thuringiensis & Larvae \\
6 & Bacillus thuringiensis kurstaki & Larvae \\
7 & Beauveria bassiana & Eggs/Larvae \\
8 & Granulosis virus & Larvae \\
9 & Metarhizium anisopliae & Eggs/Larvae \\
10 & Nucleopolyhedrosis virus & Larvae \\
\hline
\end{tabular}

Source: (CABI, 2019)

\section{Botanical:}

Natural pesticide that is derived from plants having defensive properties is known as Botanical pesticides. More than 6000 plant species from at least 235 plant families have been screened for pest control properties.According to the laboratory studies neem seed powder is found to be the effective in killing FAW larvae causing over $70 \%$ of mortality (Maredia, 1992). Azadirachtin (from neem) and pyrethrins (from pyrethrum) are the most widely used products (Assefa et al., 2019).The botanical pesticides are biodegradable, environmentally safe, less harmful to farmers and consumers, and often safe to natural enemies and hence amenable for use in biocontrol based on IPM strategies (Prasanna et.al., 2019, p. 76). Bio-pesticides are made from plant-derived pesticides and are harmless to natural environment. Bio-pesticides are substance or mixture of substance that are intended to suppress pest and prevent the damage or loss that they caused. Plant derived pesticides like 
neem based bio-pesticides can be used to control the larva of FAW as it is easily available to the local market. Different researches conducted by researcher shows that seeds or leaves of plants of Meliaceae family (Azadirachta indica) and Asteraceae family (Pyrethrum) and other plants such as Tephrosia vogelii or Thevetia nerifolia are showing capacity in the management of FAW. Further research needs to be done to promote botanical pesticide.

Table 7 Botanical method of FAW control

\begin{tabular}{|c|c|c|c|c|}
\hline S.N. & Species & Family & Extract & Mode of Action \\
\hline 1 & Neem, Azadirachta indica & Meliaceae & $0.25 \%$ neem oil & $\begin{array}{l}\text { Larvicidal with upto } 80 \% \text { mortality in } \\
\text { the lab }\end{array}$ \\
\hline 2 & Aglaia cordata Hiern & Meliaceae & $\begin{array}{l}\text { Hexane and ethanol } \\
\text { extracts of seeds }\end{array}$ & $\begin{array}{l}\text { Larvicidal with upto } 100 \% \text { mortality } \\
\text { in the lab }\end{array}$ \\
\hline 3 & Annona тисоsa Jacquin & Annonaceae & $\begin{array}{l}\text { Ethanolic extract from } \\
\text { seeds }\end{array}$ & Larval growth inhibition \\
\hline 4 & $\begin{array}{l}\text { Vernonia holosenicea, } \\
\text { Lychnophora ramosissia, } \\
\text { and Chromolaena chaseae }\end{array}$ & Asteraceae & $\begin{array}{l}\text { Ethanol extracts from } \\
\text { leaves }\end{array}$ & Ovicidal \\
\hline 5 & $\begin{array}{l}\text { Cedrela salvadorensis and } \\
\text { Cedrela dugessi }\end{array}$ & Meliaceae & $\begin{array}{l}\text { Dichloromethane } \\
\text { extracts of wood }\end{array}$ & $\begin{array}{l}\text { Insect growth regulating(IGR) and } \\
\text { larvicidal with upto } 95 \% \text { mortality }\end{array}$ \\
\hline 6 & $\begin{array}{l}\text { Long pepper, Piper } \\
\text { hispidinervum }\end{array}$ & piperaceae & $\begin{array}{l}\text { Essential oil from } \\
\text { seeds }\end{array}$ & $\begin{array}{l}\text { affects spermatogenesis and hence } \\
\text { egg laying }\end{array}$ \\
\hline 7 & $\begin{array}{l}\text { Chinaberry, Melia } \\
\text { azedarach }\end{array}$ & Meliaceae & $\begin{array}{l}\text { Ethanolic extracts of } \\
\text { leaves }\end{array}$ & $\begin{array}{l}\text { Antifeedant to larva; synergistic with } \\
\text { pesticide }\end{array}$ \\
\hline 8 & Jatropha gossypofolia & Euphorbiaceae & $\begin{array}{l}\text { Ethanolic extracts of } \\
\text { leaves }\end{array}$ & $\begin{array}{l}\text { Antifeedant to larva; synergistic with } \\
\text { pesticide }\end{array}$ \\
\hline 9 & Castor, Ricinus communis & Euphorbiaceae & $\begin{array}{l}\text { Castor oil and Ricinine } \\
\text { (seed extracts) }\end{array}$ & Growth ihibition and larvicidal \\
\hline
\end{tabular}

Source: (Prasanna et. al., 2019)

\subsection{Chemical control}

Chemical pesticides expose the major hazard in sustainable agriculture. However, in severe condition, the steps should be taken quickly in that case chemical pesticides are used. Until more sustainable solutions is developed, it is recommended to alternate application of contact/systemic insecticides based on pyrethroids, carbamates or organophosphates as an immediate management measure (Evans, 2017). The exact timing for applying chemicals is very important for effective pest control; both the life cycle and the time of day matter i.e. spraying when larvae are deeply embedded inside the whorls and ears of maize is ineffective; and spraying during the day is ineffective because larvae only come to feed on plants at night, dawn or dusk. Chemical pesticide provide a protection level which cannot be guaranteed by other methods, however, they are expensive to afford by poor farmers. There use isn't economically feasible to smallholder farmers, cause environmental contamination; develop resistance to chemicals and often pest resurgence. The use of chemical pesticides can be used as a last option if all mentioned measure cannot maintain the pest below economic threshold level if there seems heavy damage on leaves and whorls of leaves. One should always wear aprons and other safety measures while applying insecticides as it is harmful to human health. Synthetic pesticides like methomyl, acephate, cyfluthrin, benfuracarb, methyl parathion, carbaryl carbosulfan, lindane, chloropyrifos, diazinon, and methyl parathion are found effective to control FAW (Dhungel et al., 2019). New insecticides such as chlorantraniliprole, 
flubendiamide and spinetoram reported better mortality than traditional insecticide like lamba and novaluron (Hardke et al., 2014). However, during selection of chemical pesticide we should use less hazardous pesticide reading from level. FAO has been assigned authority by the council in 2006 and again in 2013 to assist member countries in reducing risks posed by highly hazardous pest (FAO, 2018).

\subsection{Host plant resistance}

The most effective and ideal method of combating insects that attack plant is by developing insect-resistant varieties (Luginbill, 1969). The antibiotic mechanism of plant resistance offers a biologically, economically, and environmentally sound alternative to conventional pesticides for controlling the fall armyworm (FAW), Spodoptera frugiperda (J. E. Smith)in corn, Zea mays L. Recent studies in Brazil showed cross resistance among Cry1f, Cry1Ab, Cry1 Ac and Cry1 A indicating current Cryl based plants face a challenge in managing fall armyworm but in contrast $\mathrm{Bt}$ maize containing the Vip $3 \mathrm{Aa} 20$ protein remains effective against FAW.Transgenic maize varieties with Bacillus thuringiensis (BT) have been successful in controlling FAW. There are resistant varieties on the market that suppress/control FAW and other lepidopteran pests.However, FAW resistant varieties of other crops have not yet been developed (Global Fall Armyworm Management, 2019).

\section{Fall armyworm management efforts in Nepal}

Most of people in Nepal depend on agriculture for their livelihood. Farmers of Nepal have been combatting the threat of devastating pest for long; however attack of fall armyworm across the field of maize raises the serious concern threatening food security to millions of people. In Nepal, the fall armyworm has the potential to cause maize yield losses of $20-25 \%$, which translates to the loss of more than half a million tons of the annual maize production estimated at around \$200 million (Pradhan, 2020). If the pest is left unrestrained, its impact will be huge for farmers and the economy.At present major problems affecting FAW management efforts in Nepal islack of knowledge about the plant disease and pest, their diagnosis and management practices the farmers, lack of sound contingency, lack of proper coordinated plans and policy, scientific research, surveillance, laboratory and adequate practices for management of pest which may be result of low financial status. However NGO and INGOs have been working together in the field for efficient management options in Nepal, some programmes conducted are present below:

- International Maize and Wheat Improvement Center (CIMMYT) have been focusing in creating awareness, disseminating appropriate technologies and management techniques, and strengthening the capacity of communities, institutions and government.

- The Ministry of Agriculture and Livestock Development has established a national taskforce to fight the pest. Most provinces have established similar taskforces that include researchers, agriculture extension agents, farmers and entrepreneur associations.

- Through the Nepal Seed and Fertilizer (NSAF) project, CIMMYT staff is working closely with the Ministry of Agriculture and Livestock Development, the Nepal Agricultural Research Council (NARC), the PQPMC, provincial governments, and other USAID-funded projects and development partners in Nepal. Together, they have developed integrated pest management packages, informative factsheets and surveillance guidelines.

- CIMMYT researchers have shared experiences on pest management, surveillance and scouting techniques from other countries in Asia and Africa. They have also demonstrated digital tools that will help map the spread of the pest and build accurate interpretation for better management.

- CIMMYT researchers collaborated with the Prime Minister Agricultural Modernization Project (PMAMP) to implement outreach campaigns in Banke district. This included a mobile information booth, local dissemination of audio messages, and distribution of posters and fact sheets about fall armyworm. The twoday campaign successfully raised awareness about the pest, reaching more than 1,000 farmers from four villages in maize growing areas.

- Further Plant Quarantine and Pesticide Management center has published factsheet for proper identification and management practices such as; Handpicking, monitoring and scouting, intercropping, pull-push strategy and biochemical.

- Chemical pesticide such as; Spinosad, Spinetoram, Emamectin Benzoate, Chlorantraniliprole has been recommended in suitable amount by Government of Nepal.

- "Fall Armyworm in Africa: A Guide for Integrated Pest Management," jointly produced by Feed the Future, the 
United States Agency for International Development (USAID), the International Maize and Wheat Improvement Center (CIMMYT), and the CGIAR Research Program on Maize (MAIZE), provides tips on fall armyworm identification as well as technologies and practices for effective control. This can be helpful to Nepalese farmers to control the outbreaks of the pest.

\section{CONCLUSION}

Nepalese farmers, especially maize producers have encountered the problem of fall armyworm infestations on a large scale in different parts of the country. Furthermore, the environmental condition of Nepal is found very favorable for the introduction, establishment, and spread of FAW. The colossal majority of farmers in the country are smallholders. These farmers have limitations to access to infrastructure which restrict their options for management of FAW. Due to very rapid spreading capacity its complete control is very difficult. Its entry in Nepal may bring up to $100 \%$ yield decline in maize as warned by FAO. Although the loss assessment of the pest in Nepal has not been estimated yet, CIMMYT has constantly been working to manage the pest in Nepal through evaluation of push-pull strategy in which Napier grass and Desmodium are cultivated with maize crop. Integrated pest management approach is practiced by most of the farmers which include; physical, chemical, botanical, and biological method. Biological approach of management is most effective as it uses different parasitoids, pathogens, and predators to control the best. Chemical method of control is not generally preferred as it is expensive and environmentally toxic. Plant quarantine has been established in India-Nepal border to check the entry of such harmful pest. Different related institutions and organizations have been supporting the government and the smallholder farmers to help in managing and controlling the fall armyworm in Nepal.

\section{REFERENCES}

[1] Abrahams, P., Bateman, M., Clottey, V., Cock, M., \& Colmenarez, Y. (2017). Fall Armyworm: Impacts and Implications for Africa. UK aid and CABI

[2] All JN. 1988. Fall armyworm (Lepidoptera: Noctuidae) infestations in no-tillage cropping systems. Florida Entomologist 71: 268-272.

[3] Altieri et al, M. F.-M. (2012). Agro-ecologically efficient agricultural systems for smallholder farmers: contributions to food sovereignty. Agronomy for Sustainable Development.

[4] Assefa.F .et .al. (2019). Status and control measures of fall armyworm (Spodoptera frugiperda) infestations in maize fields in Ethiopia: A review. Cogent Food and Agriculture.

[5] Batista-Pereira, L., Stein, K., Paula, A., Moreira, J., Cruz, I., \& Figueiredo, M. (2006). Isolation, identification, synthesis and field evalution of sex pheromone of the Brazilian population of Spodoptera frugiperda. J Chem Ecol., 32(5), 1085-1099.

[6] Beshir, A. R., Shrestha, H. K., \& Pradhan, B. (2019, January 9). Destructive Pest Alert: Fall Armyworm (FAW) is paving its way to Nepal. Retrieved June 22, 2020, from Research program on Maize: https://maize.org/destructive-pest-alert-fall-armywormfaw-is-paving-its-way-tonepal/\#: :text=The\%20invasive\%20agricultural\%20pest $\% 20$ Fall,threat $\% 20$ to $\% 20$ global $\% 20$ food $\% 20$ security.\&te $\mathrm{xt}=$ The $\% 20$ deadly $\% 20$ pest $\% 20$ has $\% 20$ a,the $\% 20$ Nepalese $\% 20$ farmers $\% 20$ and $\% 20$ economy.

[7] Bhusal, K., \& Bhattarai , K. (2019). A review on fall armyworm (Spodoptera frugiperda) and its possible management options in Nepal . Journal of Entomology and Zoology Studies , 7(4), 1289-1292.

[8] CABI, F. (2019). Community-Based Fall Armyworm (Spodoptera frugiperda)Monitoring, Early warning and Managemen. Training of Trainers Manual, p. 21.

[9] CABI. (2017). Invasive Species Compodium. Retrieved from CABI: https://www.cabi.org/isc/datasheet/29810

[10] CABI. (2017). Spodoptera frugiperda. Retrieved from Invasive species Compendium: https://www.cabi.org/isc/datasheet/29810

[11] Capinera, J. (2001). Order Lepidoptera- Caterpillars, moths and butterflies. In handbook of Vegetable Pests (pp. 353-510). Academic Press.

[12] Capinera.L.J. (July 1999). fall armyworm. Featured creatures .

[13] Chamberlain , K., Khan , Z., Pickett , J., Toshova , T., \& Wadhams , L. (2006). Diel periodicity in the production of green leaf volatiles by wild and cultivated host plants of stem borer moths, Chilo partellus and Busseola fusca. J. Chem. Ecol, 32, 565-577.

[14] Chimweta, M., Nyakudya, I., Jimu, L., \& Mashingadze, A. (2019). Fall armyworm [Spodoptera frugiperda (J.E. Smith)]damage in maize: management options for floodrecession cropping smallholder farmers. International journal of pest management, 1-13.

[15] Cruz, I., Figueiredo, Maria, d. L., da, S., Rafael, B., \& da, s. (2012). Using Sex Pheromone Traps in the DecisionMaking Proces for Pesticide Application against Fall Armyworm (Spodoptera frugiperda [Smith] [Lepidoptera: 
Noctuidae]) Larvae in Maize. Faculty Publications: Department of Entomology, 530.

[16] Dively, G. (2018). Management of Fall armyworm (Spodoptera frugiperda) with emphasis on Bt Transgenic Technology. Retrieved from https://usunrome.usmission.gov/wpcontent/uploads/sites/54/2018-Africa-FAW-Talk-Romepdf.pdf

[17] Early, R., Gongalez-Moreno, P., Murphy, S., \& Day, R. (2018). Forecasting the global extent of invasion of the cerear pest Spodoptera frugiperda, the fall armyworm. Neo Biota, 40, 25-50.

[18] Evans.M.O. (2017, may 16). Fall Armyworm: Most Effective and Recommended Pesticides and Controls. Myfarm.

[19] FAO. (2017). Food Chain Crisis : . Retrieved from http://www.fao.org/food-chain-crisis/how-we-work/plantprotection/fall-armyworm/en/

[20] FAO. (2018). Integrated management of the Fall Armyworm on maize: A guide for farmers field schools in Africa. Retrieved from Food and Agriculture Organization of United nation.

[21] FAO. (2018, October 25). Fall Armyworm - an Emerging Food Security Global Threat. Retrieved June 21, 2020, from https://www.ippc.int/en/news/fall-armyworm-anemerging-food-security-global-threat/

[22] FAO. (2018a). FAO launches mobile application to support fight against Fall Armywor in Africa. Retrieved from

http://www.fao.org/news/story/en/item/1106850/icode/

[23] FAO. (2018c). FAW Guidance Note 2: Fall Armyworm Scouting. Rome: Food and Agriculture Organization (FAO)

[24] FAO. (2019, December 19). Fall armyworm. Retrieved 18 June, 2020, from Food and Agriculture Organizations of the United Nations: http://www.fao.org/fallarmyworm/en/\#: :text=Fall\%20armyworm\%20(FAW)\% 2C\%20Spodoptera,of $\% 20$ millions $\% 20$ of $\% 20$ smallholder $\% 20$ farmers.

[25] FAO. (2020). Food and Agriculture Organizations of the United Nations. Retrieved July 17, 2020, from http://www.fao.org/fall-armyworm/monitoring-tools/fawmap/en/

[26] FAO. (2020, May 13). GIEWS - Global Information and Early Warning System. Retrieved June 21, 2020, from Food and Agriculture Organizations of the United Nations:

http://www.fao.org/giews/countrybrief/country.jsp?code= NPL

[27] Firake.M.D, B. ( June 2019 ). Fall Armyworm: Diagnosis and Managementt (An extension pocket book). Umiam793 103, Meghalaya, India: The Director, ICAR Research Complex for NEH Region.
[28] Firake.M.D, B. (2019). Fall Armyworm: Diagnosis and Management. Umiam-793 103,Meghalaya, India: ICAR Research Complex for NEH Region.

[29] Frerot, B., Leppik, E., Groot, A., Unbehend, M., \& Holopainen, J. (2017). Chemical Signatures in PlantInsect Interactions. N. sauvion, D. Thiery, and P.-A. Calatayud (pp. 139-177). Advances in Botanical research

[30] G.Ravi, J. R. (2019). Bio rational integrated pest management modules and on-farm biorational inputs. National Institute of Plant Health Management,.

[31] GC, Y., Dhungel, S., Ghimire, K., Devkota, S., \& GC, A. (2019). Fall aaaarmyworm: Global Status and Potential Threats For Nepal. The Journal of Agriculture and Environment, 20.

[32] Global Fall Armyworm Management (2019). Programmatic Pesticide Evaluation Report And Safer Use Action Plan (Persuap), 11.

[33] Goergen , G., Kumar , P. L., Sankung, S. B., Togola, A., \& Tamò, M. (2016). First Report of Outbreaks of the Fall Armyworm Spodoptera frugiperda (J E Smith) (Lepidoptera, Noctuidae), a New Alien Invasive Pest in West and Central Africa. PLOS ONE, 11(10).

[34] Groote, H. D., Kimenju, S. C., Munyua, B., Palmas, S., Kassie, M., \& Bruce, A. (2020). Spread and impact of fall armyworm (Spodoptera frugiperda J.E. Smith) in maize production areas of Kenya. Agriculture, Ecosystems \& Environment, 292, 106804.

[35] Gross, H., \& Pair, S. (1986, Sep). The Fall Armyworm: Status and Expectation of Biological Control with Parasitoids and redators. Florida Entomological Society, 69(3), 502-515.

[36] Hailu, G., Niassy, S., Zeyaur, K., Ochatum, N., \& Subramanian, S. (2018). Maize-legume intercropping and push-pull for management for fall Armyworm, Stemborers, and striga in Uganda. Agron J, 110(6), 25132522.

[37] Hardke, J., Lorenz, I., \& Leonard, B. (2014). Opportunities to manage fall armyworm (Lepidoptera: Noctuidae)On Bollgard IIVR cotton with reduced rates of insecticides. J. Cotton Sci., 18, 59-67.

[38] Heinrichs.A.E. (2018). Pest Risk Assessment of the Fall Armyworm,Spodoptera frugiperda in Egypt. Innovation Lab for Integrated Pest Management, 12.

[39] Hoy, M. (2013). Insect population ecology and molecular genetics. M.A. Hoy, Insect Molecular Genetics (Third Edition) (pp. 591-659). Academic Press.

[40] Hruska , A., \& Gould , F. (1997). Fall armyworm (Lepidoptera: Noctuidae) and Diatraea lineolata (Lepidoptera: Pyralidae): impact of larval population level and temporal occurrence on maize yield in Nicaragua. Journal of Economic Entomology, 90(2), 611622. 
[41] Hruska, A. (2019, September). Fall armyworm (Spodoptera frugiperda) management by smallholders. CAB Reviews Perspectives in Agriculture Veterinary Science Nutrition and Natural Resources , pp. 1-11.

[42] Hunt, T., Highley, L., Witkowski, J., Young, L., \& Hellmich, L. (2001). Dispersal of adult European corn borer (Lepidoptera:CRambidae) within and proximal to irrigated and non-irrigated corn. J Econ. Entomol., 94, 369-377.

[43] Ivan, C., Figueiredo, Corrêa, M. d., Silva, d., \& Braga, R. (2012). Using Sex Pheromone Traps in the DecisionMaking Process for Pesticide Application against Fall Armyworm (Spodoptera frugiperda [Smith] [Lepidoptera: Noctuidae]) Larvae in Maize Faculty Publications. (p. 530). Department of Entomology.

[44] Jeyraman, S. (2017). Field crops Production and Management. New Delhi: Oxford and IBH publishing Co. Pvt Ltd., I.

[45] Khatiwada, D. Y. (2019, Nov 11). Economic Survey 2018/2019. Retrieved from Ministry of Finance: https://mof.gov.np/uploads/document/file/compiled $\% 20$ ec onomic\%20Survey\%20english\%20725_20191111101758.pdf

[46] Knoema. (2020, Februry). Nepal - Maize production quantity. Retrieved June 21, 2020, from https://knoema.com/atlas/Nepal/topics/Agriculture/CropsProduction-Quantity-tonnes/Maize-

production\#: :text=In\%202019\%2C\%20maize\%20produ ction $\% 20$ for,average $\% 20$ annual\%20rate $\% 20$ of $\% 202.64 \%$ 25.

[47] Kumbhar, R. A. (2019). Current Status and Management of Fall Armyworm in India. Research Gate.

[48] Li, M.; Zhao, C.; Li, D.; Yang., X.; Sun, C.; Wang, Y. (2007). Towards developing an early warning system for cucumber disease for greenhouse in china. International conference on Computer and computing Technologies in Agriculture: CCTA 2007: Computer and Computing Technologies in Agriculture VII, (pp. 1375-1378).

[49] Luginbill, p. (1969). Developing resistant plant-the ideal method of controlling insects. USDA-ARS Prod.

[50] Maharani, Y., Dewi, K. V., Puspasari, L., Rizkie, L., Hidayat, Y., \& Dono , D. (2019). Cases of Fall Army Worm Spodoptera frugiperda J. E. Smith (Lepidoptera: Noctuidae) Attack on Maize in Bandung, Garut and Sumedang District, West Java. Jurnal Cropsaver, 2(1), 3846 .

[51] Malo, E., Bahena, F., Miranda, M., \& Valle-Mora, J. (2004). Factor affecting the trapping of males of Spodoptera frugiperda (Lepidoptera. Noctuidae) with pheromones in Mexico. Florida Entomol., 87(3), 288-293.

[52] Maredia KM, S. O. (1992). Effects of neem,Azadirachta indica on six species of insect pests. Tropical Pest Management.
[53] Midega, C., Pittchar, J., Pickett, J., Hailu, G., \& Khan, Z. (2018). A climate-adapted push-pull system effectively controls fall armyworm, Spodoptera frugiperda (J E Smith), in maize in East Africa. Crop protection 105, 1015.

[54] Mihm, J. A. (1994). Insect Reistant Maize Recent Advances and Utilization. International symposium. International Maize and WHeat Improvement Centre (CIMMYT).

[55] Mooventhan.P, S. B. (2019). Integrated Management of Fall Armyworm in Maize. NATIONAL INSTITUTE OF BIOTIC STRESS MANAGEMENT.

[56] Mwangi.K.D. (2019,may). Fall armyworm Identification,monitoring and management option for maize in Kenya. Fall Armyworm Technical Brief for Maize in Kenya.

[57] Poudel, S. (2020, January 15). Fall Armyworm: A Menace For Nepali Farmers. Retrieved June 17, 2020, from The Rising Nepal: https://risingnepaldaily.com/detour/fall-armyworm-amenace-for-nepali-

farmers\#: :text=An\%20invasive $\% 20$ pest $\% 2 \mathrm{C} \% 20 \mathrm{Fall} \% 2$ 0armyworm,to $\% 20$ have $\% 20$ come $\% 20$ from $\% 20$ India.\&te $\mathrm{xt}=$ According $\% 20$ to $\% 20$ pest $\% 20$ experts $\% 2 \mathrm{C} \% 20$ Fall,kin ds\%20of\%20crops $\% 20$ including $\% 20$ maize.

[58] Poudel, S. (2020, june 19). Fall Armyworm: . Retrieved from The Rising Nepal: https://risingnepaldaily.com/detour/fall-armyworm-amenace-for-nepali-farmers

[59] Pradhan.B. (2020, april 7). Collective efforts to fight fall armyworm in Nepal. CIMMYT.

[60] Prasanna, B., Huesing, J. E., Eddy, R., \& Pcschko, V. M. (2018). Fall Armyworm in Africa: A Guide for integrated Pest Management,First Edition. Mexico,CDMX: CIMMYT.

[61] Prasanna, B., Huesing, J., Eddy, R., \& Virginia, R. (2019). Fall Armyworm in frica, A guide for integrated Pest Management. Mexico:USAID and CIMMYT.

[62] Reis, L., Oliveira, L., \& Cruz, I. (1988). Doru luteipes Biology and potential in Spodoptera Control. Brazilian Agriculture Research, 23, 333-342.

[63] Rwomushana, I., Bateman, M., Beale, T., Beseh, P., Cameron, K., Chiluba, M., et al. (2018, October). Fall Armyworm: Impacts and Implication for Africa; Evidence Note Update. CABI: Oxfordshire.

[64] Sarmento , R. D., Aguiar, d. R., Vieira, S., de Oliveira , H., \& Holtz , A. (2002). Biology review, occurrence and control of Spodoptera frugiperda (Lepidoptera: Noctuidae) in corn in Brazil. Biosci. J, 18, 41-48.

[65] Shorey, H., Summers, C., Sisk, C., \& Gerber, R. (1994). Disruption of pheromone communication in Spodoptera exigua (Lepidoptera:Noctuidae) in tomatoes, alfalfa, and cotton. Environmental Entomology, 1529-1533. 
[66] The Himalayan Times. (2020, May 25). Armyworm severely affects maize production. Retrieved June 19, 2020 , from https://thehimalayantimes.com/business/armywormseverely-affects-maize-production/

[67] Wang, D., Chen, T., \& Dong, J. (2013). Research of the early warning analysis of crop disease and insect pests. International Conference on Computer and Computing Technologies in Agriculture: CCTA 2013: Computer and Computing Technologies in Agriculture VII, (pp. 177187).

[68] Zanolli, G. (2018). Integrated management of the Fall Armyworm on maize. Rome, Italy: Food and Agriculture Organizatiosn of the United Nations (FAO). 